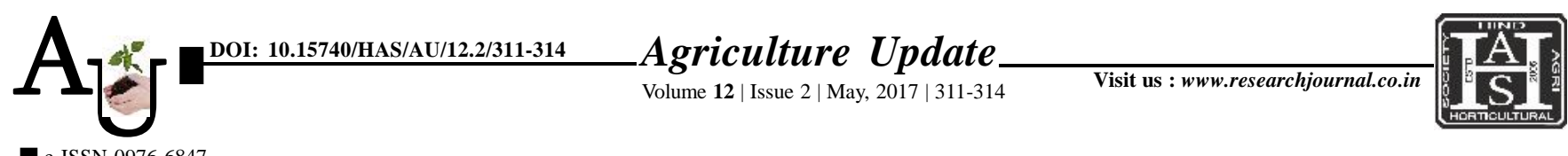

e ISSN-0976-6847

\title{
Research Article: Economic and physical constraints faced by the Research Scholars while using internet of Agriculture Science in MPUAT, Udaipur (Rajasthan)
}

Article Chronicle:

Received :

11.02.2017;

Received :

11.04.2017;

Accepted :

25.04.2017

KEY Words:

Economic, Physical contraints, Internet, Higher education
SUMMARY : Internet has become a way of life for majority of higher education students all around the world. For most of universities and college students, the internet is a functional tool, one that has greatly changed the way they interact with each other and with information as they go about their studies. Considering the importance of the internet utilization the present investigation. The present study was purposively being conducted in Rajasthan College of Agriculture. Udaipur due to the reason that this College is the oldest Agricultural College in Rajasthan state and enjoys more and adequate facilities of internet surfing for agricultural students, especially for research scholars at central library as well as in their respective departments and Hostels as compared to other Agricultural Colleges in Rajasthan. Considering the importance of the internet utilization the present investigation "Attitude and Utilization Pattern of Internet among the Research Scholars of Agriculture Science in MPUAT, Udaipur Rajasthan".

How to cite this article : Choudhary, L.R. and Bhimawat, B.S. (2017). Economic and physical constraints faced by the Research Scholars while using internet of Agriculture Science in MPUAT, Udaipur (Rajasthan). Agric. Update, 12(2): 311-314; DOI : 10.15740/HAS/AU/12.2/311-314.
L.R. CHOUDHARY Department of Extension Education, Rajasthan College of Agricultural, UDAIPUR (RAJASTHAN) INDIA

See end of the article for authors' affiliations 